\title{
Thyroid Cancer TNM Finding v7
}

National Cancer Institute

\section{Source}

National Cancer Institute. Thyroid Cancer TNM Finding v7. NCI Thesaurus. Code C89145.

A finding about one or more characteristics of thyroid cancer, following the rules of the

TNM AJCC V7 classification system. Both the histologic diagnosis and the age of the patient are of such importance in the behavior and prognosis of thyroid cancer that these factors are included in this staging system. (from AJCC 7th Ed.) 